\title{
Underweight increases the risk of pulmonary tuberculosis in adult
}

\author{
Galuh Chandra Irawan*, Ani Margawati*, and Ali Rosidi**
}

\begin{abstract}
*Department of Nutrition, Faculty of Medicine, Diponegoro University, Semarang **Science Program Study of Nutrition, Muhammadiyah University Semarang

Correspondence:

BACKGROUND

Tuberculosis (TB) is a leading cause of morbidity and mortality, especially in middle- and low-income countries. The risk of developing TB may be related to nutritional status. Socioeconomic and behavioral factors are also shown to increase the susceptibility to TB infection. The objective of this study was to determine nutritional factors as risk factors of pulmonary TB in adult.
\end{abstract}

Galuh Chandra Irawan

Department of Nutrition,

Faculty of Medicine,

Diponegoro University

Gedung G, Jln. Prof. Soedarto, SH,

Tembalang Semarang 1269

Email: chandragaluh50@gmail.com

Univ Med 2017;36:4-10

DOI: 10.18051/UnivMed.2017.v36.4-10 pISSN: 1907-3062 / eISSN: 2407-2230

Received October 22, 2016

Accepted for publication April 7, 2017

This open access article is distributed under a Creative Commons Attribution-Non Commercial-Share Alike 4.0 International License

\section{METHODS}

This was an observational study of case control design. The study subjects were community members consisting of 19 adult cases of pulmonary tuberculosis and 38 controls. Data on nutritional intakes were obtained by semiquantitative food frequency questionnaire (FFQ), while smoking behavior, history of DM, body mass index, education, and income were obtained by structured interviews. The data were analyzed by independent $\mathrm{t}$-test and logistic regression for calculation of the odds ratio (OR).

\section{RESULTS}

The bivariate test showed that the adequacy levels for energy ( $\mathrm{OR}=6.8$; 95\% CI: $1.51-30.54)$, protein ( $\mathrm{OR}=5.1 ; 95 \%$ CI: $1.52-17.14)$, vitamin A $(\mathrm{OR}=4.2 ; 5 \%$ CI: $1.31-13.54)$, vitamin $\mathrm{C}(\mathrm{OR}=3.8 ; 95 \%$ CI: $1.21-12.36)$, selenium $(\mathrm{OR}=4.2 ; 95 \% \mathrm{CI}: 1.34-13.58)$, body mass index $(\mathrm{OR}=4.4 ; 95 \%$ CI: 1.32-14.35) and smoking behavior (OR=3.7; 95\% CI: 1.15-11.9), were significant risk factors for pulmonary tuberculosis. Multiple logistic regression test showed that low body mass index $\left(<18.5 \mathrm{~kg} / \mathrm{m}^{2}\right)(\mathrm{OR}=6.0$; $95 \%$ CI: $1.32-27.18$ ) was a the most influential risk factor of pulmonary tuberculosis.

\section{CONCLUSION}

Low body mass index is the most influential risk factor for pulmonary tuberculosis incidence in adult. Nutrition profile in adult is an important determinant of TB incidence.

Keywords: Pulmonary tuberculosis, body mass index, energy, smoking behavior, adult 


\section{INTRODUCTION}

Pulmonary tuberculosis is a directly transmissible disease caused by Mycobacterium tuberculosis. Mycobacterium tuberculosis mostly attacks the lungs, but may also affect other organs. (1) Pulmonary tuberculosis is a communicable disease that is still attracting global attention, since to date there is no single country that is free of pulmonary tuberculosis. ${ }^{(1)}$ The number of patients with pulmonary tuberculosis in the world is increasing annually. The results of a WHO survey in 2013 showed that there were approximately 9 million patients with pulmonary tuberculosis, with more than half $(56 \%)$ living in Southeast Asia and the Western Pacific region. ${ }^{(1)}$ Indonesia currently ranks third as one of the countries with the largest numbers of pulmonary tuberculosis cases in the world after China and India, with the number of patients reaching 325,582 in 2013. ${ }^{(1)}$ The prevalence of tuberculosis in Central Java ranks fifth at $0.4 \%$. $^{(2)}$ Banjarnegara district in 2013 had a prevalence of $0.3 \%$ per 100.000 inhabitants. ${ }^{(3)}$ The number of pulmonary tuberculosis patients in 2014-2016 in Karangkobar subdistrict showed a fluctuating trend, with 14 cases in 2014, 123 suspected and 30 confirmed cases in 2015 and 19 cases in May 2016. ${ }^{(3)}$ Apart from home environmental health factors, nutritional status is also associated with the incidence of pulmonary tuberculosis. ${ }^{(4)}$ Inadequate intakes of protein and energy result in excessive utilization of the energy reserves of the body, thus causing weight loss and biochemical abnormalities. ${ }^{(5)}$

One study states that energy adequacy level affects nutritional status. ${ }^{(6)}$ Undernutrition may increase the risk of pulmonary tuberculosis, since poor nutritional status may undermine the immune system and facilitate aggravation of the tuberculosis. ${ }^{(7)}$ Pulmonary tuberculosis may cause nutritional deficiency from decreased appetite, thus influencing nutrient intakes, with consequent changes in metabolic processes. The association between poor nutrition and pulmonary tuberculosis has been demonstrated by the BCG vaccine trial conducted in the US in 1960 and it has been estimated that undernourished children have a two-fold risk of pulmonary tuberculosis as compared with wellnourished children. ${ }^{(8)}$

Nutrients such as vitamin A and zinc are micronutrients that play an important role in immunity. In addition, other antioxidant compounds such as selenium, vitamin $\mathrm{C}$, vitamin $\mathrm{D}$, vitamin $\mathrm{E}$ and iron may assist in maintaining the host defences in a healthy condition, by preventing oxidative processes and inflammatory responses. ${ }^{(8)}$ Smoking behavior is also a factor that is associated with pulmonary tuberculosis incidence, in addition to nutrient intakes. ${ }^{(9)}$ One study showed that there is an association between smoking and pulmonary tuberculosis incidence and that smokers have a 3.1-fold higher risk for pulmonary tuberculosis than nonsmokers. ${ }^{(9)} \mathrm{Up}$ to the present, pulmonary tuberculosis has been associated solely with poor nutrition caused by environmental factors and the epidemiological spread of the disease, so that there is a need for a more specific study on nutrient intakes, in order to know the nutrient adequacy levels at risk for pulmonary tuberculosis. ${ }^{(10)}$ Previous studies on nutritional status as risk factor have not shown consistent results. A study conducted in rural India stated that there was no association between body mass index and pulmonary tuberculosis incidence. ${ }^{(11)}$ Therefore a study is needed that aims to determine nutritional status as risk factor for pulmonary tuberculosis incidence in adults.

\section{METHODS}

\section{Research design}

The study was of case-control observational design and conducted at Puskesmas Karangkobar in Banjarnegara District, Central Java, between July and August 2016.

\section{Research subjects}

The subjects of this study were adult males and females aged 19-63 years, consisting of 19 cases of pulmonary tuberculosis and 38 controls 
(non-tuberculosis cases), yielding a total of 57 subjects. The total number of study subjects was arrived at on the basis of a total sampling of cases that were registered during the previous 6 months at Puskesmas Karangkobar as patients with pulmonary tuberculosis. The inclusion criteria in this study were subjects diagnosed with pulmonary tuberculosis who were positive for acid-fast bacilli and had positive radiographs, community members with suspect pulmonary tuberculosis, and healthy community members living with pulmonary tuberculosis patients, who resided in the catchment area of Puskesmas Karangkobar, Banjarnegara District, and were willing to participate in the study. The exclusion criteria were pulmonary tuberculosis patients with complications.

\section{Assessment of nutrient intakes}

Nutrient intakes were obtained from the results of interviews performed by the investigators using semi-quantitative food frequency questionnaires. The assessed nutrient intakes comprised energy, protein, vitamin A, vitamin $\mathrm{C}$, and selenium. Nutrient adequacy levels were calculated using the Nutrisurvey 2007 program and were based on the Indonesian Recommended Daily Allowances (IRDA) for 2013. Energy and protein adequacy levels were categorized as poor if $<90 \%$ of IRDA and optimal if $\geq 90 \%$ of IRDA. ${ }^{(12)}$ Vitamin A, vitamin $\mathrm{C}$ and selenium adequacy levels were categorized as poor if $<77 \%$ of IRDA and optimal if $\geq 77 \%$ of IRDA. ${ }^{(13)}$

\section{Anthropometric measurements}

Assessment of body mass index (BMI) of the study subjects was performed by the investigators. The BMI values of the study subjects were obtained from measurements of body weight before receiving treatment for 6 months and divided by height. BMI was categorized as underweight if $<18.5$, normal if $\geq 18.5-24.9$, and overweight if $>25-29.9$. $^{(14)}$

\section{Smoking habits}

Smoking behavior was obtained through structured interviews. The instruments used were the list of interview questions and the informed consent form. The associated data were presence of active smoking behavior at a frequency of more than once on the day previous to the establishment of the diagnosis of pulmonary tuberculosis. ${ }^{(15)}$

\section{Statistical analysis}

Data analysis was performed by means of the independent t-test and logistic regression. Multiple logistic regression was performed to control for possible confounding factors and to identify factors that are independently associated with undernutrition. A $p$ value of less than 0.05 was used to declare the presence of a statistically significant association between variables.

\section{Ethical clearance}

This study was conducted after obtaining approval from the ethical commission under no.774/EC/FK-RSDK/2016.

\section{RESULTS}

Table 1 shows that for the characteristics of age and gender there were no differences ( $p>0.05$ ) between the group of cases and the group of controls.

Table 1. Demographics distribution of cases $(n=19)$ and controls $(n=38)$

\begin{tabular}{lccc}
\hline & Cases & Controls & \multirow{2}{*}{$\mathbf{p}$} \\
\cline { 2 - 3 } & $\mathbf{n ( \% )}$ & $\mathbf{n ( \% )}$ & 0.406 \\
\hline Age (years) & $31.0 \pm 17.3$ & $32.0 \pm 13.6$ & \\
Gender & & & 0.633 \\
$\quad$ Male & $9(47.4)$ & $14(36.8)$ & \\
$\quad$ Female & $10(52.6)$ & $24(63.2)$ & \\
\hline
\end{tabular}


Table 2. Bivariate logistic regression of several nutritional risk factors for pulmonary tuberculosis

\begin{tabular}{|c|c|c|c|c|c|}
\hline \multirow[t]{2}{*}{ Risk factor } & & \multicolumn{2}{|c|}{$\begin{array}{c}\text { Pulmonary tuberculosis } \\
\text { category }\end{array}$} & \multirow[t]{2}{*}{$\mathbf{p}$} & \multirow[t]{2}{*}{ OR $05 \% \mathrm{CI}$ ) } \\
\hline & & Cases (\%) & Controls (\%) & & \\
\hline Adequacylevel for energy(Cal) & $\begin{array}{l}\text { Poor } \\
\text { Optimal }\end{array}$ & $\begin{array}{l}7(70.0) \\
12(25.5)\end{array}$ & $\begin{array}{c}3(30.0) \\
35(74.2)\end{array}$ & 0.011 & $\begin{array}{c}68 \\
(1.51-30.54)\end{array}$ \\
\hline Adequacylevel for protein (g) & Poor & $11(57.9)$ & $\begin{array}{l}8(42.1) \\
30088)\end{array}$ & 0.016 & $\frac{5.1}{(152-1714}$ \\
\hline Adequacylevel for vitamin A (mcg) & $\begin{array}{l}\text { Poor } \\
\text { Optimal }\end{array}$ & $\begin{array}{l}12(52.2) \\
7(20.6)\end{array}$ & $\begin{array}{l}11(47.8) \\
27(79.4)\end{array}$ & 0.023 & $\begin{array}{c}42 \\
(1.31-13.54)\end{array}$ \\
\hline Adequacylevel for vitarmin $\mathrm{C}$ (mg) & $\begin{array}{l}\text { Poor } \\
\text { Optimal }\end{array}$ & $\begin{array}{l}11(57.9) \\
8(42.1)\end{array}$ & $\begin{array}{l}10(26.3) \\
28(73.7)\end{array}$ & 0.042 & $\begin{array}{c}38 \\
(1.21-12.36)\end{array}$ \\
\hline Adequacylevel for selenium (mcg) & $\begin{array}{l}\text { Poor } \\
\text { Optimal }\end{array}$ & $\begin{array}{l}12(52.2) \\
7(36.8)\end{array}$ & $\begin{array}{l}11(28.9) \\
27(71.1)\end{array}$ & 0.026 & $\begin{array}{c}42 \\
(1.34-13.58)\end{array}$ \\
\hline Body mass index $\left(\mathrm{kg} / \mathrm{m}^{2}\right)$ & $\begin{array}{l}\text { Low } \\
\text { Normal/ high }\end{array}$ & $\begin{array}{l}11(57.9) \\
8(42.1)\end{array}$ & $\begin{array}{c}9(23.7) \\
29(76.3)\end{array}$ & 0.031 & $\begin{array}{c}4.4 \\
(1.32-14.35)\end{array}$ \\
\hline Smoking behavior & $\begin{array}{l}\text { Yes } \\
\text { No }\end{array}$ & $\begin{array}{l}13(48.1) \\
6(20.0)\end{array}$ & $\begin{array}{l}14(51.9) \\
24(80.0)\end{array}$ & 0.046 & $\begin{array}{c}3.7 \\
(1.15-11.9)\end{array}$ \\
\hline
\end{tabular}

Table 2 lists the risk factors for pulmonary tuberculosis. Poor adequacy levels for energy and protein were risk factors for pulmonary tuberculosis incidence, with respective OR values of $6.8(95 \% \mathrm{CI}=1.51-30.54)$ and 5.1 $(95 \% \mathrm{CI}=1.52-17.14)$. Poor adequacy levels for vitamin $\mathrm{A}$, vitamin $\mathrm{C}$ and selenium were also risk factors for pulmonary tuberculosis incidence, with respective OR values of $4.2(95 \%$ $\mathrm{IC}=1.31-13.54), 3.8$ (95\% IC=1.21 - 12.36), and 4.2 (95\% IC $=1.34-13.58)$. In addition, body mass index of $<18.5 \mathrm{~kg} / \mathrm{m}^{2}(\mathrm{OR}=4.4 ; 95 \%$ $\mathrm{IC}=1.32-14.35)$ and smoking behavior $(\mathrm{OR}=3.7 ; 95 \% \mathrm{IC}=1.15-11.91)$ were risk factors for pulmonary tuberculosis incidence. Body mass index of $<18.5 \mathrm{~kg} / \mathrm{m}^{2}$ was the major risk factor for pulmonary tuberculosis incidence $(\mathrm{OR}=6.0 ; 95 \% \mathrm{CI}=1.32-27.4)$ (Table 3$)$.

\section{DISCUSSION}

Poor adequacy levels for energy were more frequently found in the group of cases than in the group of controls, whereas optimal adequacy levels for energy were more frequently found in the group of controls than in the group of cases. A similar study in the province of Nusa Tenggara Timur found that respondents with poor energy intakes were closely associated with pulmonary tuberculosis incidence. ${ }^{(16)}$ The body uses $60-70 \%$ of the total energy requirement for maintaining its basic functions, called the basal metabolism. The energy is required for the basal metabolism and such body functions as digestion, processing, and absorption of food in the digestive tract, moving, walking, working, and other activities. Inadequate energy consumption leads to

Table 3. Multiple logistic regression of significant variables of pulmonary tuberculosis

\begin{tabular}{lcccc}
\hline \multicolumn{1}{c}{ Variable } & OR & P & \multicolumn{2}{c}{ 95\%CI } \\
\hline B odym ass index & 6.0 & 0.020 & 1.32 & 27.18 \\
Adequacy level for sel erium & 3.7 & 0.096 & 0.79 & 17.61 \\
Adequacy level for vitamin A & 3.7 & 0.084 & 0.84 & 13.39 \\
Adequacy level for protein & 3.5 & 0.085 & 0.83 & 15.25 \\
Adequacy level for vitamin C & 3.0 & 0.094 & 0.82 & 11.52 \\
Smoking behavior & 2.8 & 0.152 & 0.67 & 12.29 \\
Adequacy level for energy & 1.8 & 0.485 & 0.34 & 9.35 \\
\hline
\end{tabular}


excessive utilization of the energy reserves of the body, thus resulting in weight loss and biochemical abnormalities. ${ }^{(5)}$

In the group of cases only 8 subjects had an optimal adequacy level for protein, whereas 11 of the 19 subjects had poor adequacy levels for protein. Low protein intake is a risk factor for pulmonary tuberculosis incidence, eg. energyprotein deficiency is associated with abnormal cell-mediated immunity, phagocytic function, complement system, immunoglobulin A secretion, and cytokine production. ${ }^{(7)}$ This is in agreement with a study conducted in Africa, showing that the majority of pulmonary tuberculosis patients have chronic energy-protein deficiency. ${ }^{(17)}$

Vitamin A deficiency as seen from its adequacy levels was also found in the group of cases in comparison with the group of controls. This was because there were more subjects (79.4\%) with optimal adequacy levels for vitamin $\mathrm{A}$ in the group of controls than in the group of cases. Inadequate vitamin A is a risk factor for pulmonary tuberculosis incidence. The present study is in line with another study conducted in the community of Nusa Tenggara Timur province, stating that low vitamin A intake carries a 3.2fold risk of pulmonary tuberculosis. ${ }^{(16)}$ On the other hand, a study conducted in Delft, Western Cape, South Africa, found no relationship between vitamin A intake and pulmonary tuberculosis incidence. ${ }^{(18)}$

In the group of cases, $57.9 \%$ of the community members had poor adequacy levels for vitamin C, whereas in the group of controls, $26.3 \%$ had poor adequacy levels for vitamin C. This shows that in the group of controls the adequacy level for vitamin $\mathrm{C}$ was higher than that in the group of cases. The study by Johnkennedy et al. ${ }^{(19)}$ reported that the vitamin $\mathrm{C}$ level in patients with tuberculosis tends to be low, which results in decreased total serum antioxidant levels in patients with tuberculosis. The low antioxidant level is caused by inadequate intake and increased free radicals in the phagocytosis of Mycobacterium. These results agree with the study by Madhavi et al., ${ }^{(20)}$ who found that tuberculosis patients receiving high doses of vitamin $\mathrm{C}$ for 2 weeks showed increased total antioxidants. These results are supported by a study in Bandung, reporting that administration of vitamin $\mathrm{C}$ is of benefit for increasing the antioxidant level in patients with pulmonary tuberculosis. ${ }^{(21)}$

Poor adequacy level for selenium is a risk factor for pulmonary tuberculosis incidence. This may be seen from the number of subjects with pulmonary tuberculosis who had poor adequacy levels for selenium, namely $52.2 \%$, when compared with the number of healthy subjects who had poor adequacy levels for selenium, i.e. only $28.9 \%$. Our study results are supported by a study in India, stating that selenium levels in the blood of patients with pulmonary tuberculosis are lower than in healthy persons. ${ }^{(21)}$ Selenium supplementation may improve the antioxidant status in patients with pulmonary tuberculosis on standard treatment, thus assisting the healing process. ${ }^{(22)}$

Low body mass index was more frequently found in the group of cases, while in the group of controls only a few had low body mass index. The majority of the controls had normal body mass index, while some had a higher than normal body mass index. Body mass index may be said to be a risk factor for pulmonary tuberculosis. The results of a study in Aceh showed a significant association between nutritional status (body mass index) and pulmonary tuberculosis incidence. ${ }^{(4)}$ A similar study conducted in Indian communities also found an association between body mass index and pulmonary tuberculosis. ${ }^{(24)}$ However, a study in connection with body mass index among adult females in rural India showed no differences in body mass index before and after 6 months of treatment. ${ }^{(11)}$ The study also showed no differences in body mass index among male patients who dropped out of the study. ${ }^{(11)}$ This was caused by a low motivation for taking food among patients with pulmonary tuberculosis.

Smoking behavior was frequently found both in the group of cases and in the group of controls, since mountain communities are avid smokers, 
for warming the body, in spite of its impact on their health. Smoking increases the risk of infection with Mycobacterium tuberculosis and the risk of the disease developing and leading to death among patients with pulmonary tuberculosis. ${ }^{(25)}$ This signifies that smoking behavior is a risk factor for pulmonary tuberculosis incidence. Our study results showed an association between smoking and pulmonary tuberculosis incidence, with smokers being 3.1 times at higher risk of pulmonary tuberculosis in comparison with non-smokers. ${ }^{(8)}$

A cohort study in rural China found no significant association between smoking behavior and pulmonary tuberculosis incidence. ${ }^{(15)}$ Another study also reported no significant association between smoking behavior and pulmonary tuberculosis incidence, because smoking was counterbalanced by high nutritional intakes, thus decreasing the risk of infection with pulmonary tuberculosis. ${ }^{(26)}$

A limitation of the present study lies in the use of the semiquantitative FFQ to determine the intakes of the nutrients under study, thus requiring a strong recall capacity. Another limitation is the lack of assessment of serum albumin, vitamin $\mathrm{A}$, vitamin $\mathrm{C}$ and selenium. The study was of case-control design, therefore the occurrence of recall bias may have influenced the collected data.

This study proves that low nutrient intake is a risk factor for contracting tuberculosis. Nutritional supplementation should be aimed at those individuals with poor nutritional status, in order to improve it, which will reduce the risk of contracting tuberculosis.

\section{CONCLUSIONS}

Low body mass index is a risk factor for pulmonary tuberculosis, after controlling for energy adequacy level. Further studies are required to evaluate the effect of nutritional supplementation on tuberculosis incidence in adults.

\section{CONFLICT OF INTEREST}

There was no conflict of interest between the authors and the study subjects.

\section{ACKNOWLEDGMENTS}

We thank the Head and staff of Puskesmas Karangkobar, Banjarnegara district, Central Java and the pulmonary tuberculosis patients and their families who allowed the principal investigator to conduct the study and obtain the data at the aforementioned Puskesmas.

\section{CONTRIBUTORS}

GCI contributed to drafting the manuscript and the study design. GCI, AM, and AR contributed to data collection, analysis and interpretation. GCI and AM contributed revising manuscript critically for important intellectual content. All authors read and approved the final manuscript.

\section{REFERENCES}

1. World Health Organization. Global tuberculosis report. Geneva: World Health Organization. 2014.

2. Kementerian Kesehatan Republik Indonesia. Riset kesehatan dasar (Riskesdas) tahun 2013. Jakarta: Kementerian Kesehatan Republik Indonesia; 2013.

3. Dinas Kesehatan Provinsi Jawa Tengah. Riset kesehatan dasar (Riskesdas) tahun 2013. Semarang: Dinas Kesehatan Provinsi Jawa Tengah; 2013.

4. Mulyadi, Suangkupon R, Dermawan I. Profil penderita tuberkulosis paru di pesisir pantai Aceh Barat Daya (Kajian di Puskesmas Biangpidie). J Respir Indones 2011;31:105-8.

5. Hatta M, Supriatmo, Ali M, et al. Comparison of zinc-probiotic combination therapy to zinc therapy alone in reducing the severity of acute diarrhea. Paediatrica Indonesiana 2011;51:1-6.

6. Manalu HS. Faktor-faktor yang mempengaruhi kejadian TB paru dan upaya penanggulangannya. J Ekologi Kesehatan 2010; 9:1340-4. 
7. World Health Organization. Global tuberculosis control: surveillance, planning, financing. Report of WHO expert committee. WHO technical report series. Geneva: WHO;2007.

8. Narasimhan P, Wood J, Macintyre CR, et al. Risk factors for tuberculosis. Pulm Med 2013. Article ID 828939, 11 pages. http://dx.doi.org/10.1155/ 2013/828939.

9. Alavi-Naini R, Sharifi-Mood B, Maliheh M. Association between tuberculosis and smoking. Int J High Risk Behav Addict 2012;1:71-4.

10. Cegielski JP, McMurray DN. The relationship between malnutrition and tuberculosis: evidence from studies in humans and experimental animals. Int J Tuberc Lung Dis 2004;8:286-98.

11. Bhargava A, Chatterjee M, Jain Y, et al. Nutritional status of adult patients with pulmonary tuberculosis in rural central India and its association with mortality. PLoS ONE 2013;8:e77979. doi: 10.1371/journal.pone. 0077979 .

12. Hardinsyah. Angka kecukupan energi, protein, lemak dan serat makanan. Prosiding Widyakarya Pangan dan Gizi VIII; 2004 Mei 17-19; Jakarta; 2004.p.323-27.

13. Gibson RS. Principles of nutritional assessment. $2^{\text {nd }}$ ed. New York: Oxford University Press; 2005.

14. Maro I, Lahey T, MacKenzie T, et al. Low BMI and falling BMI predict HIV- associated with tuberculosis: a prospective study in Tanzania. Int J Tuberc Lung Dis 2010;14:1447-53.

15. Chen W, Shu W, Wang M, et al. Pulmonary tuberculosis incidence and risk factors in rural areas of China: a cohort study. PLoS ONE 2013;8:e58171. doi: 10.1371/journal.pone. 0058171 .

16. Pakasi TA, Kariadi E, Wibowo Y, et al. Vitamin A deficiency and other factors associated with severe tuberculosis in Timor and Rote Islands, East Nusa Tenggara Province, Indonesia. Eur J Clin Nutr 2009:63:1130-5.
17. Dheda K, Schwander SK, Zhu B, et al. The immunology of tuberculosis: from bench to bedside. Respirology 2010;15:433-50.

18. Lombardo CC, Rina S, Visser ME. The nutritional status of patients with tuberculosis in comparison with tuberculosis-free contacts in Delft, Western Cape. S Afr J Clin Nutr 2012; 25:180-5.

19. Johnkennedy N, Onyinyechi AS, Chukwunyere NNE. The antioxidant status and lipid peroxidation product of newly diagnosed and 6 weeks follow up patients with pulmonary tuberculosis in Owerri, Imo state, Nigeria. Asian Pacific J Tropical Dis 2011;2:292-4.

20. Madhavi M, Samudram P, Kumar H, et al. Effect of antioxidant vitamins $\mathrm{C}$ dan $\mathrm{E}$ supplementation on its plasma levels and on lipid profile in pulmonary tuberculosis patients. Am J Infect Dis 2009;5:263-72.

21. Zakiyyah ER, Gurnida DA, Kartasasmita CB. Pengaruh pemberian vitamin $\mathrm{C}$ terhadap perubahan kadar total antioksidan serum pada penderita tuberkulosis paru. Sari Pediatri 2014; 16:2-7.

22. Ramakrishnan K, Sharma SP, Shenbagarathai $\mathrm{R}$, et al. Serum selenium levels in pulmonary tuberculosis levels with and without HIV/AIDS. Retrovirology 2009;6:P76. doi: 10.1186/17424690-6-S2-P76.

23. Seyedrezazadeh E, Ostadrahimi A, Mahboob S, et al. Effect of vitamin $\mathrm{E}$ and selenium supplementation on oxidative stress status in pulmonary tuberculosis patients. Respirology 2008;13:294-98. doi: 10.1111/j.1440-1843. 2007.01200.x.

24. Gupta KB, Gupta R, Atreja A, et al. Tuberculosis and nutrition. Lung India 2009;26: 9-16.

25. Wijaya AA. Merokok dan tuberkulosis. J Tuberculosis Indones 2012;8:18-23.

26. Leung CC, Lam TH, Ho KS, et al. Passive smoking and tuberculosis. Arch Intern Med 2010;170:287-92. 